\title{
No longer the elephant outside the room: Why the Ukraine Crisis reflects a deeper shift towards German leadership of European foreign policy ${ }^{1}$
}

\author{
by Nicholas Wright \\ nicholas.wright@ucl.ac.uk
}

\begin{abstract}
:
Germany's position as Europe's predominant economic power has long been recognised. In recent years it has also emerged as a leading European foreign policy actor, although its willingness and capacity to play an explicit leadership role are debated. In particular, the 'geo-economic' analyses of Kundnani (2014) and Szabo (2015) argue that German foreign policy is increasingly focused on narrow calculations of national interest resulting in a decline in the instinctive multilateralism that has characterised its international engagement since 1949. This article uses the German response to the current Ukraine crisis to contest these arguments. Examining both German engagement with the EU's Common Foreign and Security Policy, a crucial component of its foreign policy making, and its response to the Ukraine crisis, the article contends that far from becoming more unilateral, a more vigorous German multilateralism is emerging. This seeks to fully utilise all available multilateral channels and in turn reflects how far the centre of gravity in European foreign policy-making has shifted to Berlin.
\end{abstract}

KEYWORDS: German foreign policy; CFSP; Ukraine; multilateralism; geo-economics 


\section{Introduction}

The Ukraine crisis that erupted in 2014 is perhaps the most serious to affect Europe and its security structures since the Balkan wars of the 1990s. Following Russia's annexation of Crimea, it suggested that the years of peace and East/West rapprochement following the Cold War were over, to be replaced by heightened tension and geopolitical uncertainty. Indeed, so serious was the crisis that a senior UK Foreign Office official remarked that after a 25-year hiatus they were having 'to learn how to do geo-politics again'.2

The international response has been extensive, albeit with limited success. The three main institutional components of Europe's security architecture - the EU, NATO and the OSCE - have each sought to develop and maintain a coherent strategy including: robust EU sanctions; ${ }^{3}$ capability- and capacity-building efforts by NATO; ${ }^{4}$ and the OSCE's Special Monitoring Mission to Ukraine, one of its 'highest profile' interventions. ${ }^{5}$ Finally, and perhaps most interestingly given the importance of the 'minilateral' E3+3 negotiations over Iran's nuclear programme, 6 French and German leaders have met at regular intervals with their Russian and Ukrainian counterparts through the so-called 'Normandy Format' to seek a permanent resolution to the crisis.

The centrality of Germany to all these efforts through both formal and ad hoc multilateral channels is no surprise. The relationship between Berlin and Moscow has historically been hugely important to both sides. Germany is a vital trading partner for Russia, importing major quantities of natural gas, while Russia represents a key market for some of Germany's leading exporters, meaning the Ukraine crisis has the potential to cause Germany significant economic harm. Unsurprisingly, therefore, Berlin has expected to play a key role in facilitating a durable settlement. Moreover, as Europe's most influential power, it has been expected to take the lead both by its continental partners and the US and Russia. ${ }^{7}$ The crisis has therefore created a demand for explicit German leadership in a key issue of European security. Whereas in the past it was wary of accepting such responsibilities, what is interesting is the extent to which it has been both willing and able to do so in this case. The crisis is thus a useful lens through which to consider how Germany's international engagement, particularly on security questions, has evolved.

Since the foundation of West Germany, there have been debates around the type of international power Germany can and should be. In 1949, the new German state publicly abrogated both the right and means to assert itself internationally in a clear and necessary rejection of its previous history of militarism. Instead, a state of 'semi-sovereignty' was publicly embraced that would appease and sooth neighbours and former enemies. In foreign and defence terms, this was reflected in its enthusiastic embrace of European integration through NATO and what is now the EU. In the years since the end of the Cold War, these debates have become more intense, reflecting a range of concerns including: the challenges from apparently endless international crises; US demands that Europe take more 
responsibility for its own security; and questions over whether Germany can and should once again behave as a 'normal' power and, consequently, what 'normal' entails.

Scholars such as Hans Kundnani and Stephen Szabo have offered an important contribution to this debate in their characterisation of Germany as a 'geo-economic' power. ${ }^{8}$ Building on Edward Luttwak's 1990 thesis that military power was being superseded in international affairs by commercial power, ${ }^{9}$ they contend that for Germany a significant transformation has occurred first in how its national interest is determined, and then in the means by which it is pursued internationally. Crucially, they argue that Germany's traditional Westbindung is weakening as it becomes increasingly decoupled from the multilateral institutions and normative ties which have anchored it in the international system for so long. Instead, the 'capture' by national commercial and financial interests of foreign policy-making is resulting in the emergence of a narrower, more transactional and less normative foreign and security policy.

Germany's response to the Ukraine crisis enables us to test these claims, particularly whether a shift away from multilateralism towards a more unilateral, nationally-focused foreign policy is occurring. The argument made here is that although the 'geo-economic' thesis offers a useful theoretical basis for exploring the importance of economic power within today's international system, it is less convincing when applied to the particular case of Germany. Rather, and as the Ukraine crisis demonstrates, Germany has become more willing to accept an explicit leadership role within European foreign policy-making. This in turn highlights the major shift in the centre of gravity in European foreign policy-making to Berlin, something that German foreign policy-makers have recognised and are gradually - if at times reluctantly - embracing. The article begins by discussing the 'geo-economic' thesis. It then examines how German leadership of European foreign policy has developed in the context of the EU's Common Foreign and Security Policy (CFSP) before considering the specific case of the Ukraine. Overall, it argues that a re-invigorated German multilateralism has the potential to have a profound impact on wider questions of European foreign and security policy. 


\section{Geo-economics, reluctant hegemony and the end of Westbindung?}

What kind of international actor is Germany today? There has been extensive debate around this question since reunification. Given its geographical centrality and economic predominance within Europe, the main lines of argumentation can be captured in the question 'European Germany or German Europe?', the assumption being that a more assertive Germany must inevitably lose its European vocation. ${ }^{10}$ Historically, there have been two core components to post-war Germany's international engagement. The first is multilateralism, reflected particularly in its membership of the EU and NATO which have provided 'the two pathways' through which it has defined and pursued its security and economic prosperity at the European level. ${ }^{11}$ The second is Germany's long-standing commitment to Zivilmacht (civilian power) which, despite military involvement in the Kosovo War in 1999 (a watershed moment in its post-war foreign policy evolution) and subsequent missions in Afghanistan and elsewhere, remains, with its multilateralism, the default setting for international action. ${ }^{12}$ Taken together, these reflect a rejection of the two elements that historically have proved so destructive to Germany and its European neighbours: power politics and nationalism.

But is this changing? Germany's economic strength and particularly its centrality within the Eurozone have contributed to the evolution of a 'new' Germany in recent years which challenges this orthodoxy. It remains almost inconceivable that any component of European integration would be successful without its support and participation in some form. However, its current predominance in European economic policy-making - and therefore, given the euro's international importance, in global economic policy-making - has led to a change in Europe's balance of power, particularly vis-a-vis France, its traditional partner in integration, and to fresh assessments of (and concern about) the extent of German influence. This is captured by Bulmer and Paterson's characterisation of Germany today as a 'reluctant hegemon': faced with the reality of the Eurozone crisis and its importance in resolving this, Germany's huge potential influence over policy-making is now matched by expectations for decisive action placed upon it domestically and internationally. ${ }^{13}$ Thus, while Frank-Walter Steinmeier, former Foreign Minister in both Grand Coalition governments, may play down Germany's wider influence - 'Germany has not become an economic superpower' 14 - choosing instead to emphasise its stability in a changing world, the reality is that in foreign economic policy at least, it is now Europe's indispensable power. ${ }^{15}$

Beyond economics, an important evolution has also been taking place in what was a central plank of German foreign policy during the Cold War: Ostpolitik. Willy Brandt's attempt to build East-West detente and deal with one of the perennial questions of German foreign policy - what to do about Russia - was also rooted in a desire to change the perception of Germany as an 'economic giant [but] political dwarf' - i.e. to utilise its economic power and influence in pursuit of particular foreign policy objectives. ${ }^{16}$ Since the end of the Cold War, Germany has come under increasing pressure from partners and allies 
to play a more active international role, particularly in the maintenance of security. Within Germany's political elite, the emerging recognition first that this was desirable and second that it was practically possible is reflected in a clear trajectory of change in its foreign policy since 1989. Thus, it has exchanged its status as 'political dwarf' first for reluctant participant; ${ }^{17}$ and latterly, since the generational change in political leadership marked by Gerhard Schröder's Red-Green Coalition in 1998, for a gradual if tentative willingness to lead, particularly in the context of the CFSP. Thus, the 'leadership avoidance reflex' of the past has given way to a more self-confident Germany, freed from the 'constraints of semisovereignty' which defined its Cold War identity, ${ }^{18}$ a point is underlined by the latest German Weissbuch (Defence White Paper). ${ }^{19}$

What has this 'freedom' entailed for the direction of German foreign policy-making? For Kundnani and Szabo, the basis of German power and influence remains its economy, while a continuing reluctance to resort to military force - or even sanction its use by others reflects the continuing strength of the Zivilmacht mentality. This tells only part of the story, however. They argue that alongside this, a more fundamental change has occurred in German statecraft: the deliberate and instrumental use of economic strength in pursuit of national objectives reflects its emergence as a geo-economic power.

As noted, geo-economics was first suggested by Luttwak as part of a wider attempt within IR to explain the changes being wrought by the end of the Cold War. For Luttwak, geo-economics represented 'the logic of war in the grammar of commerce' - i.e. while international relations remain adversarial, for developed states military power was no longer an appropriate (or relevant) instrument and was being supplanted by alternative, economic 'weapons' of coercion. ${ }^{20}$ Given, Germany's explicit rejection of military power as an instrument of statecraft in any but the most extreme circumstances and its burgeoning economic strength, geo-economics therefore offers a potentially useful framework for analysing its post-Cold War statecraft. In particular, they map the development of an interest-driven geo-economic approach to Russia and China, the corollary of which is a loosening of Germany's institutional and normative ties to the West (Westbindung).

Kundnani locates Germany's emergence as a geo-economic power in its growing reliance on exports from the 2000s onwards..$^{21}$ By 2010 these contributed $48 \%$ of German GDP and were accelerated by weaknesses in the euro.22 Despite the 2008 global financial crisis, Germany's economy was thriving while those of its partners were in the doldrums; indeed, its export-based economic policies were themselves contributing to the crisis by driving Eurozone divergence rather than convergence. ${ }^{23}$ German economic interests were thus being pursued at the expense of solidarity with fellow Eurozone states.

Kundnani and Szabo contend that the impact of this economic re-balancing on German foreign policy has been profound. A new 'realism' can be discerned in the governments of both Schröder and Merkel whereby the normative underpinnings of the Bonn Republic's foreign policy have given way to the more hard-nosed, interest-driven policy of its Berlin successor. Schröder's governments initially pursued an updated version 
of Ostpolitik that saw economic engagement and co-operation with China and Russia as the best means to encourage reform and democratisation - i.e. Wandel durch Annährung ('change through rapprochement'). However, over time economic priorities, particularly the need to strengthen market access for German companies, meant this policy became far more transactional, i.e. Wandel durch Handel ('change through trade'), ${ }^{24}$ and was ultimately so ineffective it was mockingly referred to as 'trade without change'.25 This reflected the reality that the German government was 'under great pressure to prioritise economic growth' over other foreign policy objectives, ${ }^{26}$ and was 'ced[ing] overall grand strategy' to key domestic business constituencies. ${ }^{27}$

What does this shift mean for how Germany engages with traditional partners and allies? Kundnani sees in this loosening of Germany's Westbindung the possibility of 'a postWestern' foreign policy emerging. ${ }^{28}$ Since the end of the Cold War, and notably since the generational change in Germany's political leadership, he maintains, the imperatives that led German governments to base their security outlook in Atlanticism have diminished, while their willingness to stand up for shared Western norms and show solidarity with partners can no longer be assumed. Three episodes in particular support this. The first was Germany's decision to oppose the US-led invasion of Iraq in 2003, contributing to the deepest division among the Western powers since 1945 (although it was joined in this by France). The second was the Schröder government's controversial approval in 2005 of plans by Gazprom to construct the Nordstream II gas pipeline, bypassing transit states like Ukraine and Poland and leaving them potentially vulnerable to Russian pressure whilst weakening the EU's overall energy security. ${ }^{29}$ The third was Germany's abstention in the UN Security Council vote on intervention in Libya in 2011 which saw Germany align with Russia and China in opposing the British, French and US position. Taken together, these supposedly indicate a Germany whose support can no longer be assumed in a US-dominated international system, particularly given the latter's increasingly confrontational relations with two of Germany's most important markets: Russia and China. Thus, the contention being made is an emerging equidistance as the alternative to Westbindung, reflecting what Szabo sees as Germany's future: a country with 'few allies and many customers'. 30 This, in turn, has serious implications for the effective functioning of the multilateral institutions traditionally so central to German foreign policy.

What, though, do such examples really tell us? Certainly, they indicate the emergence of a more robust Germany, but do they reflect the profound change Kundnani and Szabo contend, or are they merely indicative of a country more comfortable with its international influence? Three arguments are offered to support this latter assertion:

\section{(i) All foreign policies are interest-driven.}

Whatever its normative underpinnings since 1949, in this German foreign policy is no different to its British, French or American equivalents. It has always sought to protect, pursue and promote opportunities for its enterprises and citizens. For these a stable, 
predictable, rules-based international system is a prerequisite. Kundani and Szabo are implying, however, that a particular set of domestic commercial interests now predominate. This is resulting in the abandonment of traditional, post-war approaches to foreign policymaking rooted in a normative understanding of the world and how Germany should act within it, and constructed on multilateral institutional pillars, particularly NATO and the EU.

Certainly there will be tensions (sometimes frequent) between any state's international commercial and economic interests and the normative objectives or principles it may assign itself. Moreover, it is no surprise that particular commercial actors lobby for particular policies given it is their 'objective [...] to influence political decisions' when their interests are affected. ${ }^{31}$ But this is different from saying that commercial interests have 'captured' German foreign policy vis-a-vis China and Russia to the consequent detriment of its wider international strategy. Szabo may contend that German public policy is now constrained by the influence of private enterprises involved in Russia; ${ }^{32}$ however, as Kluever has demonstrated in the context of EU lobbying, it is challenging to establish a clear causal link between lobbying and particular political outcomes. ${ }^{33}$ Moreover, as discussed below, in responding to the Ukraine crisis German foreign policy has actually adopted a course contrary to the preferences of a range of German corporations. ${ }^{34}$ This seems to support the claim by Michael Roth, German Minister for Europe (2013-17), that '[v]alues, not just money, are what really matters!'35 In short, the desire of commercial interests to influence foreign policy is nothing new and provides insufficient evidence that Germany is now practising a new form of geo-economic statecraft that abandons the key tenets that have guided its foreign policy for decades.

\section{(ii) The 'geographical imperative'}

Szabo is not alone in making the point that Germany's proximity to Russia, along with the latter's obvious importance as an international power, means there is little alternative to engagement. ${ }^{36}$ Consequently, the idea of a 'new' Ostpolitik is merely the latest manifestation of attempts by German policy-makers since 1949 to construct a stable basis for bilateral relations. As Frank-Walter Steinmeier states, Germany's place at the centre of Europe means 'neither isolation nor confrontation is a prudent policy'. ${ }^{37}$ The question is the extent to which German policy can be said today to be 'Europeanised' - i.e. whether its approach to Russia is reflective of - and reflected in - collective European approaches to Russia, particularly through the EU and NATO, or whether Germany is pursuing a unilateral strategy to the detriment of its European partners?

Germany has long enjoyed a 'special relationship' with Moscow. As Forsberg notes, it is considered 'of fundamental importance' to European security: indeed, since the end of the Cold War and reunification, Germany has come to be regarded as Russia's 'strategic partner' in Europe. ${ }^{38}$ That particular German governments have nurtured this relationship is also clear, the relationship between Schröder and Putin being especially noteworthy. 
However, the fact remains that political necessity requires German engagement at some level - even when relations cool or there is antipathy between leaders (e.g. Merkel and Putin). Germany's location means its policy cannot be based on a binary choice between 'East and West' - for Berlin, Russia's isolation is 'unacceptable and must be avoided at all costs' ${ }^{39}$ Rather, relations must be set within a wider context of establishing and maintaining a rules-based international system, and based on its own historical experience of Russia. 40 There will obviously be differences between Berlin and key allies on Russia at times. The fact remains - and as the Merkel government's response over Ukraine demonstrates - where Germany sees Russian actions as threatening, ${ }^{41}$ it is willing to address these as such, even to the detriment of commercial interests. ${ }^{42}$ Again, the necessity of engagement does not mean the abandonment of core German foreign policy principles.

\section{(iii) The weakening of Germany's 'multilateral vocation'}

The logical consequence of the geo-economic thesis is a gradual de-coupling of Germany from the key multilateral institutions that have provided the foundation of its international engagement as well as its conceptions of its own place in the world since 1949. A geo-economic German foreign policy will be more unilateral and interest-driven and therefore likely to create tensions particularly with its membership of organisations such as NATO and the EU. The evidence, however, suggests otherwise. First, the latest Weissbuch re-iterates Germany's commitment to 'maintaining a rule-based international order' and to 'strengthening the ability of NATO and the EU to act', ${ }^{43}$ something underlined by proposed increases in defence spending up to 2020.44

Meanwhile, an examination of Germany's bilateral energy relationship with Russia, whose significance is highlighted by Kundnani and Szabo, is also revealing. The contention is that the importance of this relationship dilutes Germany's commitment to EU efforts to increase co-operation and integration through the European Energy Union. ${ }^{45}$ Kundnani notes, for example, the opposition by E.ON Ruhrgas, Gazprom 's partner in the construction of Nordstream II, to further liberalisation of 'the European gas market [...] to reduce dependence on Russia', while Szabo argues that Germany prioritises its bilateral relationship with Russia at the expense of progress in the Energy Union. ${ }^{46}$ The logical consequence of a more geo-economically driven German foreign policy should thus be resistance to EU efforts to develop its Energy Union, particularly where they threaten this bilateral relationship.

The reality is somewhat different. In 2010 Germany introduced its Energiewende (energy transition) policy with the aim of ensuring a secure supply of affordable and environmentally sustainable energy from a diverse range of sources. ${ }^{47}$ As part of this, dependence on external sources of natural gas has been falling and as a consequence of the Energiewende the share of Russian gas in Germany's energy mix is 'steadily reducing'. ${ }^{48}$ Moreover, not only does Berlin feel the Energiewende complements the key Energy Union goal of enhancing EU energy security;49 it sees the development of the Energy Union itself 
through 'building, regulating and managing markets' as contributing directly to this latter goal. ${ }^{50}$ Continuing German government support for Nordstream II thus seems based more on a strategic objective of 'keeping channels for dialogue and economic cooperation open' than satisfying the demands of German commercial energy interests at the expense of its European partners. ${ }^{51}$

The ongoing debates around normalisation, Zivilmacht and Westbindung remind us of the challenge to how we conceptualise and understand Germany's evolution as an international actor since the end of the Cold War. Given its economic and political significance in Europe, it should come as no surprise that Germany's external partners expect it to play a role commensurate with its capacities. Equally, and as the 2016 Weissbuch demonstrates, recognition of this is increasingly apparent domestically. How Germany plays that role has been the main question in this first section, with the focus on the geo-economic thesis posited particularly by Kundnani and Szabo. While their argument that a profound transformation has occurred in German foreign policy since 1989 is not new, their claims as to the nature of that transformation are, particularly that an increasing unilateralism leaves Germany's multilateral vocation much more 'contingent'. ${ }^{52}$ Having offered a conceptual counter to these claims, the remainder of this article focuses on this issue of Germany's multilateral commitment. Specifically, it examines German engagement with the EU's CFSP, the most important institutional location for its multilateralism. It argues that not only does Germany's multilateral vocation remain as strong as ever, but that it has facilitated and legitimised the emergence of German leadership of European foreign and security policy, something we see particularly in the context of the European response to Russian action in the Ukraine. 


\section{Activism in the CFSP: Germany emerges as Europe's foreign policy leader}

Since its establishment in 1991, the CFSP has been key to European efforts to develop a coherent and unified approach to a range of international issues. It has also been central to German efforts to build trust and confidence with European partners..$^{53}$ The CFSP is considered 'essential' to German foreign policy: 'this is the forum where we can actually express our foreign policy' 54 and 'the framework in which [...] security and defence policy happens. Everything else is [...] a complete non-starter.' 55 This section explores how Germany seeks to influence and lead within the CFSP. It identifies three main leadership approaches: (i) shared; (ii) by example; and (iii) by mediation. While these are not the only potential categories of German engagement, they provide a useful basis for seeing how it pursues its interests and objectives, as well as its continuing emphasis on multilateralism and Zivilmacht, and minimising the potential for isolation. In particular, they show how Germany in recent years has started playing a more explicit leadership role, but one that is framed around 'responsibility'.

Shared Leadership is Germany's preferred approach to policy-making in the CFSP. One official stated that 'no initiative can be successful if Germany alone presents it - we need partners' ${ }^{56}$ While partnership with France remains the bedrock of Germany's European engagement, in issues of foreign and security policy they have been less close, despite a joint call in 2016 for a new European Security Compact. ${ }^{57}$ In part this reflects different strategic priorities: France focuses more on the Mediterranean and Africa while Germany prioritises the eastern neighbourhood. Following the UK's Brexit vote, however, Franco-German support for closer defence and security co-operation and particularly the launch of Permanent Structured Co-operation (PESCO) in late 2017 underlines their efforts to develop a closer partnership. ${ }^{58}$

An important channel of shared leadership with France has been the Weimar Triangle which also draws in Poland. For Germany, Poland's role in the East is 'analogous' to that of France in the West; 59 the Weimar Triangle thus brings the three together in 'a forum of equal partners at the heart of Europe'. ${ }^{60}$ While its remit covers a range of matters, it has enabled Germany to co-operate with Poland and France on a number of foreign policy initiatives, giving them the potential to be a highly influential 'core' group which could be 'indispensable' to the EU's security policy agenda, ${ }^{61}$ particularly following Brexit. ${ }^{62}$

Several officials highlighted the importance of the Weimar Triangle. One noted a gradual shift in recent years in Warsaw's traditionally Atlanticist alignment to a more European perspective, enabling the grouping to produce serious policy proposals. These have included plans to create of a permanent CIV-MIL EU headquarters for crisis management, a long-standing German objective. ${ }^{63}$ This also formed part of Poland's ambitious agenda for its 2011 Council Presidency which prioritised the development of CSDP in order to improve the EU's crisis response capabilities. ${ }^{64}$ Poland's agenda, drawn up 'in close consultation with France and Germany', was set out in a letter from the Weimar group which was subsequently accepted by the EU's Foreign Affairs Council in January $2011 .{ }^{65}$ More recently, the Weimar grouping has been an important means of consultation on the Ukraine crisis. 66 
The most influential leadership grouping for Germany has been with Britain and France. The three have launched a number of joint initiatives that have been significant in shaping the development of the CFSP and ESDP/CSDP from the outset. For example, using its Council Presidency in 1999, Germany was instrumental in the establishment of the ESDP following the 1998 Anglo-French St Malo Agreement even if operating somewhat in 'reactive mode'. ${ }^{67}$ Perhaps the highest-profile example of their shared leadership were the E3+3 negotiations with Iran. When revelations about Iran's nuclear programme first emerged in 2002, there was 'a clear decision' 68 by Germany, France and Britain on the need to act - 'it was natural [...] that the three of us should be doing something together' ${ }^{69}$ Consequently, while the E3 worked closely with EU partners to agree and maintain the EU's sanctions regime on Iran, they were determined to represent the European position in the international community's response: 'it has to do with [...] economic weight and the weight we can throw when it comes to sanctions [...] That was fairly quickly accepted. ${ }^{\prime} 70$

Agreement between them has not always been straightforward, but where they 'decided on something [...] then there's quite a leverage...[to] push something through' and 'the chances of success are very high' ${ }^{71}$ Underpinning this is the intense and frequent contact across their foreign and defence ministries, and at the highest government levels. One official involved with CSDP noted that on urgent issues he could be in contact with his French and British counterparts several times a day.72 British and French officials expressed similar sentiments, ${ }^{73}$ while a Swedish diplomat also concurred, noting particularly their cooperation on Iran. ${ }^{74}$

Leadership by example sees Germany seeking to position itself as to be a hub around which other states, particularly the smaller, can coalesce on particular issues or policy areas. A diplomat working in a Political and Security Committee working group declared:

'You will find easily, and that's really easily, fifteen or a dozen member states who come up to us in every meeting basically and ask: "what do you think about it because we would like to think the same way you do." They're looking for leadership.' 75

This reflects both the structural reality of operating within the CFSP and the role conception German officials assign their country in this arena. Germany views itself as representing an alternative centre of gravity to France and Britain, holding positions that are generally considered more mainstream and easier for other states to align with, 'not because they liked us, but because we were an instrument for them' ${ }^{76}$ This is allied with a sense of responsibility to protect the interests of smaller states, considered a 'trademark' of German foreign policy:

' $[\mathrm{M}]$ any, especially the Eastern Europeans $[[\ldots]$ recognise there are possibly three centres of gravity inside the EU, [so] which is the one that actually takes on board our national interests?'77

An example was Germany's promotion of a non-paper on reforming the European External Action Service sent to then High Representative, Catherine Ashton, in December 2011. The Auswärtiges Amt's intention was to raise various German concerns prior to the publication of the High Representative's own review in 2013, but also to demonstrate how widely these 
were shared. Consequently, the final document was co-signed by 11 other foreign ministers. ${ }^{78}$

Germany's approach to its two-year term on the UN Security Council (2011-12) provides a further example. Describing this as 'a special responsibility it has to live up to', ${ }^{79}$ it deliberately adopted a different strategy to Britain and France. While they have actively avoided explicit linkages between their P-5 status and EU membership, Germany made a conscious effort to do so, declaring its role to be 'self-evidently as a representative of all UN members and particularly EU member states' 80 :

'[Britain and France] do not want to be appearing to coordinate a European position [...] We actually want to play this European perspective and regularly tell our partners what we are doing, why we are doing it, and thus basically living up to a sort of a European seat.' 81

Germany sought to promote the position of the EU itself within the UN, for example by sponsoring a 2011 resolution to give it independent speaking rights within the General Assembly. ${ }^{82}$ However, its ability to play such a role was limited: it lacked the structural advantages of permanent Security Council membership, while its abstention on UN resolutions on Libya left it isolated, breaking its own long-standing rule. ${ }^{83}$ It is also important to recognise that it has not always been successful at exercising this kind of leadership. The Schröder Government was criticised, for example, for having 'betrayed its role as a champion' of the smaller member states during the Iraq crisis. ${ }^{84}$ Former Foreign Minister Steinmeier declared, however, that Germany's application for a UNSC seat for 2019-2020 reflects its continuing 'willingness to take on responsibility and to strengthen the multilateral order' .85

Finally, leadership through mediation complements the German focus on multilateralism, protecting the interests of smaller states and taking responsibility. It is particularly pertinent given the consensus bias in EU decision-making, especially in foreign and security policy. Although this is a policy area where France and Britain have traditionally predominated, they have also frequently disagreed over the direction and purpose of cooperation. As the other 'big' state, Germany has thus felt well-placed to act as balancer and mediator.

One official emphasised Germany's rejection of the idea of big states imposing their preferences: 'This is not the position that traditionally Germany would like to be seen in. This is not the picture we have [...] of ourselves' ${ }^{86}$ Another declared: 'we always respect the interests of smaller partners, and defend their interests, and that's what makes us a natural mediator' ${ }^{87} \mathrm{He}$ emphasised the centrality of the mediation role to how Germany operates, and its utility in the CFSP policy environment:

'Very often $[\ldots]$ we are the mediator, where we are actually trying to be in the centre of it. [...] it's fair to say that up until 1989 we basically followed the mainstream and we were needed sometimes to bridge gaps between extreme positions of partners. But we've never been extreme in our positions.'

The avoidance of 'extreme positions' reflects a desire to avoid isolation and a determination to build coalitions to achieve particular outcomes. Moreover, it is a role that German 
representatives have played at the highest level, with both Hans-Dietrich Genscher and Joschka Fischer highlighted as being particularly effective in this role. ${ }^{88}$

A prime example of leadership through mediation was Germany's role in the E3+3 process towards Iran. Mediation here took place at two levels. The first was within the E3+3 format by facilitating agreement between France, Britain, and the United States:

'[W]e have a pre-consultation format. That is the Americans with the 3 Europeans. So there's a 2 layer thing. So beforehand we know exactly how the others feel [...] and usually Germany had sort of kept the middle ground and was often able to bridge gaps or bridge differences between partners. [...] There's France even harder than the US. The UK in between and it's more difficult.' 89

The other level, meanwhile, involved maintaining the EU-wide consensus on the sanctions regime. This was particularly important as much of the process was not 'Brussels-driven' but went through capitals. ${ }^{90}$ With some member states unconvinced about the effectiveness of sanctions and others feeling they were too tough, German officials worked hard to maintain the line and indeed have played a similar role vis-a-vis EU sanctions against Russia. ${ }^{91}$

What this brief discussion illustrates, therefore, is both the importance Germany assigns to EU foreign policy cooperation and the intensity of its engagement in the CFSP. As the final section demonstrates, its use of this policy environment has been crucial to the shaping of the EU's response to Russia and to Germany's pre-eminent position in this process. It also underlines Germany's growing leadership role in EU foreign and security policy more generally. 


\section{The Ukraine Crisis and a more vigorous German multilateralism}

The previous section illustrated how Germany's multilateral commitment is demonstrated by its active engagement in the CFSP. Developing these themes, this section examines its leadership role in the international response to the Ukraine crisis. Adomeit, Siddi and Stewart are among those emphasising Germany's importance within the EU in securing a resolution and confronting Russia. ${ }^{92}$ This seems to confound Kundnani and Szabo's expectations that a narrower German foreign policy constrained by domestic economic interests will be less willing or able to respond meaningfully to Russian actions. Rather, it highlights, first, Germany's commitment to a strong, multilateral European response, and second how the nature of this response reflects Berlin's importance in EU foreign and security policy-making.

Germany has been an active supporter and champion of a robust and coherent international response to Russian actions in Ukraine. Indeed, to preserve the basis of Europe's security architecture which these challenged, Berlin has had no alternative than 'to put its rhetoric in action'. ${ }^{93}$ Meanwhile, Ukraine's proximity has demanded action: 'whatever happens will have an impact on Poland and Germany. There was no alternative'. ${ }^{44}$ Following the outbreak of violence and Russian intervention after the resignation of President Yanukovych in 2014, the Berlin government made clear that resolution by force was unacceptable. ${ }^{95}$ Instead, it has promoted a dual-track Zivilmacht approach 'involv[ing] enforcing economic sanctions while also continuing to communicate with Russia' ${ }^{96}$ Thus, Germany has backed the EU's range of economic and other restrictive measures, particularly since the downing of Malaysian Airlines Flight MH17.97

The UK Foreign Office has emphasised the importance of Germany in galvanising other EU member states - frequently divided over how to respond to Russia - and particularly the individual leadership of Chancellor Merkel.98 A German diplomat re-iterated this point, noting that 'the German role in the Ukraine crisis has entirely only to do with the Chancellor', although emphasising the importance of EU Heads of Government collectively in developing the sanctions regime and the determination of Chancellor Merkel 'under no circumstances [...] to be alone in this. ${ }^{99}$ It is worth noting here the impact of sanctions on the German economy: they were estimated to have cost the German pharmaceutical sector alone $€ 2.1$ billion in 2016, for example, with other sectors of the economy such as car manufacturers also significantly affected, underlining the weakness in the geo-economic arguments outlined above. Moreover, while France and Britain were unhappy with the economic impact on them, Germany and a number of smaller EU states were agreed on the need for tough action, reflecting German efforts to build consensus in favour of a robust European response. ${ }^{100}$ Indeed, the strength of this response has been perhaps the biggest surprise to President Putin. 101

As was the case with sanctions against Iran, the difficulties in maintaining a unified European position are not to be underestimated, however. As one EU official stated: 'the former CEEC states tend to be quite aggressive [over Ukraine] but they don't have the 
means to be aggressive'.102 Meanwhile, other states such as Cyprus have sought to lift sanctions. ${ }^{103}$ Balancing the multiple concerns - and historical experiences of Russia - of other, particularly smaller, states will have been a key challenge for German diplomats, reflecting efforts at leadership by example and through mediation. In evidence given to the UK's House of Lords in 2015, the Auswärtiges Amt's former Political Director Hans-Dieter Lucas argued that for Germany's response to Russia to be effective it needed to be seen as part of a broad EU consensus and be sensitive to the concerns of other Member States to avoid any impression of German high-handedness. ${ }^{104}$ This challenge was highlighted following the December 2017 European Council which approved the extension of sanctions by a further six months but only, according to Chancellor Merkel, after 'intense discussions'. 105

Alongside this, Germany has utilised additional multilateral channels to manage and reduce tensions and promote a long-term solution. In particular, it used its 2016 OSCE chairmanship to push for greater security within Ukraine and between Europe and Russia. ${ }^{106}$ Former Foreign Minister Steinmeier frequently emphasised the importance of the organisation in this regard, declaring it 'the only organisation left in which we have any East-West exchange whatsoever'; 107 that Germany had accepted the OSCE chair 'precisely because the situation is difficult; 108 and that it 'may be more important than ever' in managing the Ukraine crisis. ${ }^{109}$ This was borne out by the focus in Germany's OSCE programme on crisis management in the region, but also the promotion of a range of negotiation formats under its auspices. ${ }^{110}$

Dialogue has also been pursued at the highest levels through the 'Normandy Format' process. This provides a clear example of shared leadership: here Germany has worked closely with France to nudge and cajole Russian and Ukrainian leaderships towards a ceasefire and an agreed settlement. ${ }^{111}$ The geographical imperative again comes into play here: 'Ukraine is so much closer to Germany [...] and whatever happens will have an impact on Poland and Germany. There was no alternative.' 112 The intensity of these efforts should not be underestimated: as of 27 May 2016, the 'Normandy' process had resulted in 12 meetings of foreign ministers alone. ${ }^{113}$ Alongside this were Chancellor Merkel's efforts at personal diplomacy. ${ }^{114}$ She had personally intervened to find a solution to the Maidan protests that preceded Yanukovych's resignation in 2014. Subsequently the Russians and especially President Putin accepted the central role played by the Chancellor, regardless of their mutual antipathy. 115 This combination of formal institutional and ad hoc structures employed in mutually-supportive ways - and particularly the weight EU sanctions has given to Germany's bilateral and mini-lateral diplomacy - demonstrates both the breadth and intensity of German efforts at achieving a solution and its centrality to Europe's response. Indeed, Liana Fix describes it as being 'at the centre of a tightly-knit web of multilateral and international crisis management activities'. ${ }^{116}$

The approach and leadership styles outlined above highlight the intensity of German engagement in the Ukraine crisis reflecting among other things a determination that 
institutions such as the EU and OSCE be sufficiently robust - and be seen as such - in contributing to the 'rules-based international order' Germany depends on. ${ }^{117}$ German efforts in Ukraine thus reflect a Zivilmacht approach to leadership based on 'a mix of institutionbuilding and consensus-fostering'. ${ }^{118}$ While the ultimate success of these efforts remains in the balance, they underline the strength of Germany's commitment to 'effective multilateralism' 119 as well as its own emerging centrality to European foreign and security policy.

\section{Conclusion}

Exploring German leadership of the international response to the Ukraine crisis facilitates a deeper examination of questions around the nature of its commitment to and engagement with the multilateral institutions that have been so central to its post-war foreign policy, particularly the EU and its CFSP. Contesting claims of a 'geo-economic' Germany with a weakened commitment to traditional allies and a reduced multilateral vocation, it has argued instead that German engagement with the EU's CFSP shows a range of approaches strongly rooted in consensus-building, and designed to enhance its influence and facilitate leadership whilst accounting for the concerns and interests of partners. This can be seen particularly in its leadership of Europe's response to the Ukraine crisis through the CFSP, the maintenance of sanctions, and its efforts to utilise other channels, particular the OSCE and the ad hoc 'Normandy Format', to support and augment these efforts. The 2016 Weissbuch emphasises Germany's 'duty to take on responsibility' for European security alongside traditional allies and partners. ${ }^{120}$ After years where it hesitated on the sidelines, the Ukraine crisis underlines the new reality: Berlin is now centre stage in leading European foreign and security policy. 


\section{Endnotes:}

${ }^{1}$ I would like to thank Dr Christine Reh and Dr Marco Siddi for their helpful comments on earlier drafts of this article, as well as the two anonymous reviewers whose feedback and suggestions are greatly appreciated. This paper is an output of the project "Germany's Eastern Challenge: A 'hybrid Ostpolitik' in the making?" of the Institute of International Relations Prague and it was supported from the institutional funding provided by the Government of the Czech Republic.

${ }^{2}$ FCO internal seminar, London, January 2015.

3 EEAS, EU sanctions against Russia over Ukraine crisis, 29 March 2016. Available at: http://europa.eu/ newsroom/highlights/special-coverage/eu_sanctions/index_en.htm. Accessed: 10 October 2016.

${ }^{4}$ NATO, Relations with Ukraine, 8 December, 2015. Available at: http://www.nato.int/cps/en/natolive/ topics 37750.htm. (Accessed: 10 October 2016.)

${ }^{5}$ OSCE, Annual Report, 2014. Available at: http://www.osce.org/annual-report/2014?download=true. Accessed: 10 October 2016.

${ }^{6}$ The 'E3+3' (or P5+1) consisted of France, Germany and Great Britain, joined from 2006 by China, Russia and the United States.

7 E. Pond, 'Germany's Real Role in the Ukraine Crisis: Caught Between East and West', Foreign Affairs, 94 (2015), p.173; J. Dempsey, 'Obama and Merkel need each other to end the Ukraine crisis', Carnegie Europe, 5 May 2014. Available at: http://carnegieeurope.eu/strategiceurope/55501?lang=en. Accessed: 12 January 2018.

${ }^{8}$ H. Kundnani, The Paradox of German Power (London: C. Hurst \& Co, 2014); S. F. Szabo, Germany, Russia and the Rise of Geo-Economics (London: Bloomsbury, 2015).

${ }^{9}$ E.N. Luttwak, 'From Geopolitics to Geo-Eonomics: Logic of Conflict, Grammar of Commerce', The National Interest, Summer (1990), pp.17-23.

10 For example: S. Bulmer, C. Jeffrey and W. Paterson, Germany's European Diplomacy: Shaping the Regional Milieu (Manchester: Manchester University Press, 2000).

${ }^{11}$ L. Aggestam, 'Germany', in I. Manners and R.G. Whitman (eds), The Foreign Policies of the European Member States (Manchester: Manchester University Press, 2000), p.64.

12 H. Maull, ‘German Foreign Policy, Post-Kosovo: Still a ‘Civilian’ Power?', German Politics 9 (2), (2000) pp.1-24.

13 S. Bulmer and W. Paterson, 'Germany as the EU's reluctant hegemon? Of economic strength and political constraints’, Journal of European Public Policy, 20/10 (2013), pp.1387-1405.

14 F.W. Steinmeier, ‘Germany’s New Global Role: Berlin Steps Up’, Foreign Affairs, 95 (2016), p.106.

15 Pond, ‘Germany’s Real Role in the Ukraine Crisis’, p.176.

16 T.G. Ash, The Polish Revolution: Solidarity (Yale University Press, 1999), p.331.

${ }^{17}$ R. Wittlinger, German National Identity in the Twenty-First Century - A Different Republic After All? (Basingstoke: Palgrave Macmillan, 2010), p.118.

18 W. Paterson, 'Germany and Europe', in S. Padgett, W. Paterson and G. Smith (eds), Developments in German Politics 3 (Basingstoke: Palgrave Macmillan, 2003), p.207.

${ }^{19}$ German Federal Government, On German Security Policy and the Future of the Bundeswehr, Berlin, 2016. 
${ }^{20}$ Luttwak, 'From Geo-politics to Geo-economics', p.19.

${ }^{21}$ Kundnani, The Paradox of German Power, p.6.

22 Kundnani, p.76.

${ }^{23}$ Kundnani, p.78.

${ }^{24}$ Kundnani, p.82.

${ }^{25}$ T. Forsberg, 'From Ostpolitik to 'frostpolitik'? Merkel, Putin and German foreign policy towards Russia', International Affairs, 92 (1), (2016), pp.21-42.

${ }^{26}$ Kundnani, p.83.

27 Szabo, Germany, Russia and the Rise of Geo-Economics, p.9.

${ }^{28}$ H. Kundnani, 'Leaving the West Behind: Germany looks East', Foreign Affairs, 94 (2015), p.109.

29 'New Twists and Turns in German-Russian Gas Pipeline Saga', Deutsche Welle, 13 July 2007, http:// www.dw.com/en/new-twists-and-turns-in-german-russian-gas-pipeline-saga/a-2679905 (accessed: 10 October 2016).

${ }^{30}$ Szabo, p.144.

${ }^{31} \mathrm{H}$. Kluever, 'The contextual nature of lobbying: explaining lobbying success in the European Union', Journal of European Union Politics, 12 (4), 2011, pp.483-506.

32 Szabo, p.62.

33 Kluever, 'The contextual nature of lobbying', p.483.

${ }^{34}$ Forsberg, 'From Ostpolitik to 'frostpolitik'?', p. 34.

${ }^{35} \mathrm{M}$. Roth, Speech to the conference 'Effects of conditionality and post-conditionality on the quality of democracy in EU member states and beyond', Friederich-Ebert-Stiftung in Budapest, 8 November 2016.

36 Szabo, p.41.

${ }^{37}$ Steinmeier, ‘Germany's New Global Role’, p.4.

38 Forsberg, 'From Ostpolitik to 'frostpolitik’?', p.21-22.

${ }^{39}$ C.S. Chivvis and T. Rid, 'The Roots of Germany’s Russia Policy', Survival, 51 (2), 2009, pp.105-122.

${ }^{40}$ German Federal Government, On German Security Policy and the Future of the Bundeswehr, p. 22..

${ }^{41}$ House of Lords European Union Committee, The EU and Russia: before and beyond the crisis in Ukraine, HL Paper 115, 20 February 2015, p. 30.

42 German Federal Government, On German Security Policy, p. 31-32.

${ }^{43}$ D. Keohane, 'Constrained Leadership: Germany's New Defense Policy', CSS Analyses in Security Policy, No. 201, December 2016.

44 'Germany says boosting defence spending, demands clear US agenda', Reuters, 19 January 2017. Available at: http://uk.reuters.com/article/uk-germany-military-idUKKBN153080 (Accessed: 13 February 2017). 
45 European Commission, Energy Union Fact Sheet, 25 February 2015. Available at: http://europa.eu/rapid/ press-release_MEMO-15-4485 en.htm (Accessed: 10 October 2016).

46 Kundnani, p. 80; Szabo, p. 125.

${ }^{47}$ Bundesministerium für Wirtschaft und Energie, Energiewende: Gesamtstrategie, 2016. Available at: http:// www.bmwi.de/DE/Themen/Energie/Energiewende/gesamtstrategie.html (Accessed: 10 October 2016).

${ }^{48}$ A. Lada, M. Sklodowska, M. Szczepanik and L. Wenerski, The Energy Union: Views from France, Germany, Poland and the United Kingdom (Institute of Public Affairs, Warsaw, 2015).

49 ibid. p.88.

${ }^{50} \mathrm{~S}$. Andersen, A. Goldthau and N. Sitter, 'An Odd Pro-Market Trio: Germany, the UK and Norway' in S Andersen, A. Goldthau and N. Sitter (eds) Energy Union - Europe's New Liberal Mercantilism?

(Basingstoke: Palgrave Macmillan, 2016), p.197.

51 S. Fischer, 'Explaining Germany's contradiction: Energy Union and Nord Stream 2', Europe's World, 19 July 2016. Available at: http://europesworld.org/2016/07/19/explaining-germanys-contradiction-energyunion-nord-stream-2/\#.V dbczKZPq3 (Accessed: 10 October 2016).

52 H. Kundnani, 'Germany as a Geo-economic Power.' The Washington Quarterly, 34 (3) (2011), pp. 31-45.

53 Aggestam, ‘Germany', p. 69.

${ }^{54}$ Interview, Auswärtiges Amt.

55 Interview, German Permanent Representation to the EU.

${ }^{56}$ Interview, Auswärtiges Amt, Berlin.

57 J-M Ayrault and F-W Steinmeiner, A Strong Europe in a World of Uncertainties, 24 June 2016. Available at: http://www.auswaertiges-amt.de/cae/servlet/contentblob/736268/publicationFile/217575/160624-BMAM-FRA-DL.pdf. (Accessed: 10 October 2016).

58 P. Briançon and J. Posaner, J. 'Angela Merkel and Emmanuel Macron rekindle German-French romance', Politico, 13 July 2017. Available at: https://www.politico.eu/article/angela-merkel-and-emmanuel-macronrekindle-german-french-romance/. (Accessed: 10 January 2018)

59 J. Frasch, ‘A Fresh Impetus for German Polish Relations’ SWP Comments 14, 2009.

60 Auswärtiges Amt, Germany's foreign policy parameters. 2012. Available at: http://www.auswaertigesamt.de/EN/Aussenpolitik/AktuelleArtikel/111027-ZweiJahreAupo-node.html (Accessed: 10 October 2016).

61 A. Bendiek, 'EU Foreign Policy Perspectives - A call for the revival of the Weimar Triangle', SWP Comments 8, 2008.

62 'Germany, Poland and France revive 'Weimar Triangle' in wake of Brexit vote', EurActiv, 29 August 2016. Available at: http://www.euractiv.com/section/future-eu/news/germany-poland-and-france-reviveweimar-triangle-in-wake-of-brexit-vote/?nl ref=19456189. (Accessed: 10 October 2016.)

63 Interviews, German Permanent Representation, Brussels, and Auswärtiges Amt, Berlin.

64 Polish Ministry of Foreign Affairs, Programme of the Polish Presidency of the Council of the European Union - 1 July 2011 - 31 December 2011, 2011.

65 C. Major and F. Wassenberg, 'Warsaw's Ambitious CSDP Agenda', SWP Comments 25, 2011.

${ }^{66}$ Auswärtiges Amt, Joint statement of the Weimar Triangle Ministers for European Affairs, Warsaw, 14 June 2016. 
${ }^{67}$ Interview, Auswärtiges Amt, Berlin.

68 Interview, FCO, London.

${ }^{69}$ Interview, Auswärtiges Amt, Berlin.

70 Interview, Auswärtiges Amt, Berlin.

${ }^{71}$ Interviews, Auswärtiges Amt, Berlin.

72 Interview, Auswärtiges Amt, Berlin.

73 Interviews, FCO, London; Quai d’Orsay, Paris; French Permanent Representation, Brussels.

74 Telephone interview, Swedish Permanent Representation, Brussels.

75 Interview, German Permanent Representation, Brussels. Interviewee’s emphasis.

76 Interviews, Auswärtiges Amt, Berlin and German Permanent Representation, Brussels.

77 Interview, Auswärtiges Amt, Berlin.

${ }^{78}$ Interview, Auswärtiges Amt, Berlin. The other signatories were: Belgium, Estonia, Finland, France, Italy, Latvia, Lithuania, Luxembourg, the Netherlands, Poland and Sweden.

79 Auswärtiges Amt, Germany’s foreign policy parameters, Berlin, 2010.

${ }^{80}$ Auswärtiges Amt, Schwerpunkte: Deutschland im Sicherheitsrat, Berlin, 2011.

81 Interview, Auswärtiges Amt, Berlin.

82 Auswärtiges Amt, Bericht der Bundesregierung zur Zusammenarbeit zwischen der Bundesrepublik Deutschland und den Vereinten Nationen und einzelnen, global agierenden, internationalen Organisationen und Institutionen im Rahmen des VN-Systems in den Jahren 2010 und 2011, Berlin, 2012.

83 W. Ischinger, 'Germany after Libya: Still a responsible power?'. In Valasek, T. (ed.) All alone? What US retrenchment means for Europe and NATO (London: Centre for European Reform. 2012).

84 M. Overhaus, 'Civilian Power under Stress: Germany, NATO, and the European Security and Defense Policy'. In H.W. Maull (ed.) Germany's uncertain power: foreign policy of the Berlin Republic (Basingstoke: Palgrave Macmillan, 2006).

${ }^{85}$ F-W. Steinmeier, Speech at the opening of the 15th Ambassadors Conference Business Forum, 30 August 2016.

86 Interview, German Permanent Representation, Brussels.

${ }^{87}$ Interview, Auswärtiges Amt, Berlin.

88 Interview, Auswärtiges Amt, Berlin.

${ }^{89}$ Interview, Auswärtiges Amt, Berlin.

90 Interview, EEAS.

${ }^{91}$ Interview, German Permanent Representation, Brussels.

92 H. Adomeit, 'German-Russian Relations: Change of Paradigm versus 'Business as Usual”, Note du Cerfa 120, February 2015; M. Siddi, 'German foreign policy towards Russia in the aftermath of the Ukraine crisis: A new Ostpolitik?', Europe Asia Studies, 68 (4), (2016), pp. 665-677; S. Stewart, 'The Future of the Minsk Agreements', SWP Comments 14, March 2016. 
${ }^{93}$ C. Major, 'Germany: The (Not So) Timid Leader', Carnegie Europe, 3 February 2017. Available at: http:// carnegieeurope.eu/strategiceurope/67896 (Accessed: 10 January 2018)

94 Interview, German Permanent Representation, Brussels.

${ }^{95}$ Forsberg, p. 29.

${ }^{96}$ House of Lords, The EU and Russia, p. 30.

${ }^{97}$ European Council, 'EU restrictive measures in response to the crisis in Ukraine', 15 September 2016. Available at: http://www.consilium.europa.eu/en/policies/sanctions/ukraine-crisis/ (Accessed: 10 October 2016.)

${ }^{98}$ House of Lords, The EU and Russia, p. 28.

99 Interview, German Permanent Representation, Brussels.

100 M. Qvortrup, Angela Merkel: Europe's most influential leader (Duckworth Overlook: London, 2017), p. 301.

101 M. David, 'Member States' Relations with Russia: Solidarity and Spoilers', LSE IDEAS - Dahrendorf Forum Special Report, March 2016, pp.33-38.

102 Interview, General Secretariat of the Council of the EU, Brussels.

103 'Merkel: No end to EU sanctions against Russia', EurActiv, 19 August 2016. Available at: https:// www.euractiv.com/section/europe-s-east/news/merkel-no-end-to-eu-sanctions-against-russia/. (Accessed: 10 October 2016.)

${ }^{104}$ House of Lords, The EU and Russia, p. 32.

105 G. Gotev, 'EU leaders agree to roll over Russia sanctions 'after intense discussion', EurActiv.com, 15 December 2017. Available at: http://www.euractiv.com/section/global-europe/news/eu-leaders-agree-to-rollover-russia-sanctions-after-intense-discussion/. (Accessed: 10 January 2018)

${ }^{106}$ Auswärtiges Amt, Renewing dialogue, rebuilding trust, restoring security: The priorities of the German OSCE Chairmanship in 2016, 2016.

107 Steinmeier, Speech at the opening of the 15 th Ambassadors Conference Business Forum.

108 F-W. Steinmeier, Speech at the budget debate in the German Bundestag, 7 September 2016.

${ }^{109}$ F-W Steinmeier, Foreign Minister Frank-Walter Steinmeier on the informal meeting of the OSCE Ministerial Council in Potsdam, 31 August 2016.

110 Auswärtiges Amt, 'Renewing dialogue, rebuilding trust, restoring security’, p. 3-8.

111 Auswärtiges Amt, 'German support for Ukraine', 22 February 2016. Available at: http:// www.auswaertiges-amt.de/EN/Aussenpolitik/Laender/Aktuelle Artikel/Ukraine/

DEU Unterstuetzung_node.html (Accessed: 10 October 2016).

112 Interview, German Permanent Representation, Brussels.

113 Auswärtiges Amt, Press Release: Sanctions are not an end in themselves, 27 May 2016.

${ }^{114}$ House of Lords, The EU and Russia, p. 30.

115 Interview, German Permanent Representation, Brussels.

${ }^{116}$ L. Fix, 'Leadership in the Ukraine conflict: A German moment' in N. Helwig (ed.), Europe's New Political Engine: Germany's role on the EU's foreign and security policy, Finnish Institute of International Affairs, 2016, pp. 111-131.

117 Steinmeier, Speech at the opening of the 15th Ambassadors Conference Business Forum, 30 August, 2016. 
${ }^{118}$ N. Helwig (ed.), Europe's New Political Engine: Germany's role on the EU's foreign and security policy, Finnish Institute of International Affairs, 2016, p. 11.

119 F-W. Steinmeier, Breaches and Bridges - German Foreign Policy in Turbulent Times, Auswärtiges Amt, 27 June 2016.

120 On Security Policy and the Future of the Bundeswehr, p. 6. 